\title{
Level of Financial Literacy and Food Waste in Polish Households
}

\author{
Monika Szafrańska ${ }^{1}$, Andrzej Krasnodębski ${ }^{1}$, Zuzana Kapsdorferová ${ }^{2}$ \\ ${ }^{1}$ Department of Management and Economics of Enterprises, University of Agriculture in Krakow, Poland \\ ${ }^{2}$ Department of Management, Slovak University of Agriculture in Nitra, Slovakia
}

\begin{abstract}
The aim of the presented research is to show on food waste and determine the level of financial literacy of food consumers as a factor affecting the probability of occurrence of food waste in Polish households in comparison with selected demographic and economic factors conditioning this phenomenon. The main source of data used for analysis and conclusions was primary information obtained from own research ( $n=1021$, PAPI method). To analyze the data, total statistical indicators, the one-way analysis of variance (the F test) and the logistic regression were used. The conducted analysis demonstrates that among the elements creating financial literacy, only financial attitudes determine consumers' inclination to waste food. The higher the score obtained from this module, the less food is thrown away from households. From the group of factors that significantly determine the occurrence of food wastage, financial attitudes have the weakest impact. The strongest impact has respondent's education.
\end{abstract}

\section{Keywords}

Financial literacy, food waste, household awareness, natural resources, food chain.

Szafrańska, M., Krasnodębski, A. and Kapsdorferová, Z. (2020) “Level of Financial Literacy and Food Waste in Polish Households", AGRIS on-line Papers in Economics and Informatics, Vol. 12, No. 1, pp. 99-109. ISSN 1804-1930. DOI 10.7160/aol.2020.120109.

\section{Introduction}

Nowadays, there are ongoing discussions about food waste and food losses which is very urging problem of this planet. On one side we are fighting against hunger and on the other side we waste a lot of food. The problem with hunger will even grow in importance because of rising population in the world and the need to feed the population. The option to feed this world would not be only in increasing agricultural production, but also by decreasing of food losses and food waste. Forecasted recent calculations in a long time period vision shows that halving the food waste and food losses will occurs that instead of increasing agricultural production to $60 \%$ we will need increase the production only to $25 \%$ to enhance nutrition for 9 billion people in 2050. We have to pay high attention on responsibility for sustainability of natural resources.

$30-40 \%$ of all agricultural products and food is never eaten. This is not persist in other industries. This causes at least two kinds of costs. The first one is the economic cost and the other is the environmental cost. To the first one mentioned does not belong only the costs related to the value of products, but also the costs for agricultural and food production, including of costs for human resources inputs, financial and material inputs, storage or transport, as well the storage of unused products and their handling. The environmental cost, are linked to the exhaustion of soil and water resources, externalities caused by utilization of pesticides and chemical fertilizers, but also this refers to the water and air pollution; into consideration has to be taken the employees 'and consumers health problems. The residues are leaving their significant signs on the environment. The food losses and food waste are responsible for additional 3.3 billion tons of greenhouse gasses, which are escaping to the atmosphere (FAO, 2014). The decline on the food losses is also considered as the meaningful tool for downsizing of GHG emissions, for the creation of which is paradoxically responsible agrifood sector, despite of its main task to ensure food security and food safety. Organization of United Nations considers the food losses and food waste as the real mean for the hunger eradication and for the attainment of the permanently increasing need for sustainable 
food systems. Well, for a better economic situation of families with tighter budget, but not only those, as well as growing population in every year and environmental consequences connected with food waste, is important a free removal of the separated waste. The fact that food waste has an enormous impact on the economy as well as on environment, makes a problem of social and economic range. For this reason The European Parliament's Agriculture Committee has adopted a resolution committing members of the Commission to take radical steps to reduce food and food waste from a farm to fork by up to $50 \%$ by 2025 . Upon this initial steps there must be developed a strategy and action plan to combat food waste

The question of the food losses and food waste represents very complex problem which is calling for participation of all participants of the food chain, if the significant results should be achieved in this field. Responsibility for sustainability of the natural resources for future generation is in our hands.

As already mentioned, food waste is a paradox of the modern food system. Estimates indicate that every year almost $1 / 3$ of the amount of food produced by humans is wasted in the global food chain (FAO, 2011). At the same time, almost 821 million people are chronically undernourished due to lack of food (PCMP, 2019). Food waste implies only negative consequences, which can be classified into three categories: economic, environmental and social. From an environmental point of view, it is necessary to indicate the excessive use of water, land, energy and other resources needed for the production and distribution of food, and then for the disposal of unsold products (McCarthy and Liu, 2017; Richter and Bokelmann, 2018). Social consequences are global price increases that threaten food security, as well as increasing number of malnourished people both in developed and developing countries (Graham-Rowe et al., 2014). "On a global scale, the economic cost, based on 2009 producer prices, of the overall amount of food waste in year 2007 totalled about USD 750 billion" (FAO 2013, p. 55). Every year around 9 tonnes of food are wasted in Poland. The primary sources of wasted food in Poland are households, which account for 53 percent of all food thrown away, followed by food processing (19 percent), restaurants (12 percent), production (11 percent) and distribution (5 percent). The average Pole wastes $247 \mathrm{~kg}$ of food a year, putting Poland in fifth place in Europe, where the average is $173 \mathrm{~kg}$ per capita (PEI, 2019).
In developed countries, the greatest waste of food takes place at the end of the food chain, especially in terms of consumption. Reasons of food waste in households are manifold. Parfitt et al. (2010) and Koivupuro et al. (2012) believe that one of the main causes of food waste is incorrect in-store behaviors (impulsive buying, excessive purchase, promotions). Some scientists point to the lack of consumer knowledge of stocking food at home (Stefan et al., 2013; Plumb and Downing, 2013), bad habits related to food preparation: overcooking (Graham-Rowe et al., 2014), wrong interpretation of food label (Milne, 2013) or food provisioning routine (Evans, 2011).

This is due to cultural backgrounds, habits by which consumers are regulating their home food supplies, as well as due to absence of relevant information and knowledge, consumers are doing bigger shopping in comparison to their real needs, respectively that they do prepare more food, as they are able to consume. These all factors are leading to the fact that large amount of the prepared foodstuffs are ending in the waste. This everything is requiring qualified work with consumer awareness, in order to be more selective at decision-making during the food shopping and to deal with food in more responsible way. This is particularly important in the countries with higher living standard where is obvious systematic access to the food shopping. In these countries the consumers should be guided to the smaller, but more frequent shopping. The preference to bigger food procurements is leading to the larger food wastes.

Food waste may be reduced by changing consumer reactions towards waste, increasing awareness of poverty and hunger, and highlighting the moral implications of waste, for example by using guilt (Ratinger et al., 2016). The greatest motivator for consumer to waste lower amounts of food is the opportunity to save money. According to Baker et al. (2009) this aspect is by far more important than the ecological one leading to reducing food waste.

Reducing food waste and its consequences require an understanding of the determinants of this phenomenon. Research on determining the factors affecting the level of food waste has been conducted for many years. The investigations most often focus on determining the influence of demographic and economic factors: income (Graham-Rowe et. al., 2014; Aschemann-Witzel et al., 2017; McCarthy and Liu, 2017; Macková et. al., 2019), consumer's age (Quested et al., 2011), 
education (Cox and Downing, 2007) and number of persons in the household. (Baker et. al., 2009; Jörissen et al., 2015). Although the mentioned studies broaden the knowledge about the factors influencing food waste by consumers, the role of one of the often speculated, important factors such as the appropriate level of financial literacy of consumers has not been considered. The literature lacks studies on the impact of the level of consumer financial literacy on food waste in households. So far, no similar scientific research in this area has been conducted in Poland. The research results presented in this paper fill this gap.

The aim of the presented research is to show on food waste and determine the level of financial literacy of food consumers as a factor affecting the probability of occurrence of food waste in Polish households in comparison with selected demographic and economic factors conditioning this phenomenon.

\section{Materials and methods}

The main source of data used for analysis and conclusions was primary information obtained from own research. The research was conducted in 2019 with the PAPI method, personally by the authors on a group of 1021 respondents.

The following formula was used to estimate the minimum number of samples (n) (Szreder, 2004):

$$
n=\frac{\frac{1}{4} \cdot N}{N \cdot \frac{d^{2}}{z_{\alpha / 2}^{2}}+\frac{1}{4}}
$$

where:

$N$ - population size,

$\mathrm{z}^{2}{ }_{\alpha / 2}$ - the value of random variable $Z$ of normal standard distribution,

$d$ - statistical error.

In the studies it was assumed that the maximum statistical error of the results may amount to $+/-5 \%$. The necessary minimum sample size was set at 544 persons. The study covered 1100 respondents. Following the rejection of inconsistent and incorrectly completed questionnaires, 1021 forms were further analysed. According to the Organisation for Economic Co-operation and Development and its International Network on Financial Education (OECD INFE), to assess the level of financial literacy, the minimum sample size should be 1000 respondents (OECD, 2011).
The selection of the sample for the study was deliberate. The survey involved persons who expressed their willingness to complete the questionnaire and declared that it would take decisions to buy food alone or together with other household members. Persons who did not make such decisions did not participate in the research.

The research was carried out in the Małopolskie Province. The province was selected for two reasons. First of all, the structure of the population of a selected province by gender and age corresponds to the structure of citizens by these characteristics for the whole country (the sample was statistically representative of the Polish population by gender and age). Secondly, it was the economic calculus that made the decision. It is cheaper to conduct regional research.

The structure of the sample in terms of gender and age corresponded to the structure of the population of the Malopolskie Province and Poland in 2016 (GUS, 2017). Demographic characteristics of the sample can be seen in the Table 1.

\begin{tabular}{|c|c|c|}
\hline \multicolumn{2}{|r|}{ Specification } & $\%$ \\
\hline \multirow{2}{*}{ Gender } & Female & 52 \\
\hline & Male & 48 \\
\hline \multirow{4}{*}{ Age } & $18-35$ years & 24 \\
\hline & $36-50$ years & 32 \\
\hline & $51-65$ years & 28 \\
\hline & 66 years and more & 16 \\
\hline \multirow{3}{*}{ Education } & Vocational & 18 \\
\hline & Secondary & 50 \\
\hline & University & 32 \\
\hline \multirow{5}{*}{$\begin{array}{l}\text { Number } \\
\text { of persons } \\
\text { in the household }\end{array}$} & 1 & 5 \\
\hline & 2 & 13 \\
\hline & 3 & 21 \\
\hline & 4 & 33 \\
\hline & 5 and more & 28 \\
\hline \multirow{3}{*}{$\begin{array}{l}\text { Place } \\
\text { of residence }\end{array}$} & Village & 46 \\
\hline & A city of up to 100,000 inhabitants & 30 \\
\hline & City over 100,000 inhabitants & 24 \\
\hline \multirow{6}{*}{$\begin{array}{l}\text { Average net } \\
\text { income } \\
\text { per capita } \\
\text { in the household }\end{array}$} & Up to PLN 500 & 5 \\
\hline & PLN 501-1000 & 25 \\
\hline & PLN 1001-1500 & 22 \\
\hline & PLN 1501-2000 & 21 \\
\hline & PLN 2001-3000 & 20 \\
\hline & Over PLN 3000 & 7 \\
\hline
\end{tabular}

The questionnaire form consisted of five parts. The first part was a certificate (6 questions: age, 
education, number of persons in the household, place of residence, average net income per capita in the households). The following parts concerned particular components of financial literacy: basic financial knowledge (7 questions), financial behaviours ( 9 questions) and financial attitudes (3 questions). A set of questions proposed by the OECD INFE (2011) was used to assess the level of financial literacy of adults. The application of the OECD INFE methodology made it possible to compare the results of the study with the results presented by other authors who also used this method. The OECD INFE has defined financial literacy as follows: "A combination of awareness, knowledge, skill, attitude and behaviour necessary to make sound financial decisions and ultimately achieve individual financial wellbeing" (OECD, 2011, p. 3). The OECD INFE methodology (OECD, 2016) was used to calculate the overall indicator characterising the level of financial literacy. The target value of the index is the sum of the results obtained in the three modules forming the respondent's financial literacy: financial knowledge (0-7 points), financial behaviours (0-9 points) and financial attitudes (1-5 points). In total, the respondent could obtain a minimum of 1 credit point $(0+0+1$ point $)$ and a maximum of 21 points $(7+9+5$ points $)$. The last part of the questionnaire included questions about food waste in respondents' households. The questionnaire was pre-tested on a sample of $n=40$ participants. Only minor changes were made based on the pre-test.

To analyze the data, total statistical indicators: mean (M), minimum, maximum and standard deviation (SD), the one-way analysis of variance (the F test) and the logistic regression were used.

The basis for the one-way analysis of variance is the possibility of breaking the sum of squares of the total variance for all observation results into two components:

- sum of squares describing the variability inside the samples,

- sum of squares describing the variability between groups (populations).

To estimate the value of the $\mathrm{F}$ test, the following formula was used (Stanisz, 2011):

$\mathrm{F}=M S$ between groups : $M S$ inside groups

where:

$M S$ - Mean Squares.

The values of the $\mathrm{F}$ test above unity indicate the need to reject the $\mathrm{H}_{0}$ hypothesis.

The $\mathrm{H}_{0}$ hypothesis assumes that the averages in separate groups of respondents are the same

$\mathrm{H}_{0}: \mu_{1}=\mu_{2}=\ldots=\mu k$

$\mu$ - the average value characterizing the population;

against the $\mathrm{H}_{1}$ alternative hypothesis assuming that at least two averages differ from each other

$\mathrm{H}_{1}: \mu_{1} \neq \mu_{2}$ lub $\mu_{1} \neq \mu_{3}$ lub, $\mu_{2} \neq \mu_{3}$.

If the analysis of variance (the $\mathrm{F}$ test) does not show significance between the analyzed averages, no further tests are carried out. However, when the $\mathrm{H}_{0}$ hypothesis is rejected in the analysis of variance, it is necessary to carry out a more detailed study of the differences between the means of individual groups (post-hoc tests) (Stanisz, 2011). In order to establish statistically significant differences between the average mean, a RIR Tukey post-hoc test was performed.

On the other hand, the logistic regression model enables modelling and simulation of the probability of an event described by a dichotomous variable, depending on various independent variables. In order to carry out the analysis properly, the studied population was divided into two groups (households wasting food and households where this phenomenon does not occur). The model did not consider the amount of food waste, its value or kind of wastes.

The logistic regression model takes on a general form (Stanisz, 2011):

$P=\frac{e^{Y}}{1+e^{Y}}=\frac{1}{1+e^{Y}}$

$Y=a_{0}+b_{1} X_{1}+\ldots+b_{k} X_{k}$

where:

$e^{Y}$ - parameter,

$Y$ - dependent variable,

$a_{i}, i=0, \ldots, k-$ regression coefficients,

$X_{1}, X_{2}, \ldots, X_{k}$ - independent variables.

Using the model, the odds indicator $(W)$ can be determined from the formula:

$W=\frac{P_{i}}{1-P_{i}}$

The odds indicator is the ratio of the probability of occurrence $P_{i}(i=1,2, \ldots k)$ of a given event in the $k$-th unit to the probability of its non-existence. All the hypotheses were verified with a horizontal significance of $\alpha=0.05$. 
Apart from primary sources, Polish and foreign literature on the subject was also used to achieve the goal. The results of the research were presented in a descriptive and tabular form.

\section{Results and discussion}

In order to carry out a statistical analysis, the studied population was divided into two groups: those who declare to throw away food and those who do not waste food. $45 \%$ of respondents admitted to wasting food in their households. Test results are consistent with those from other tests. According to the Kantar Millward Brown Institute's 2018 report, just over $40 \%$ of Polish society throws away food (Banki Żywności, 2018).

The main reasons for food throwing away by respondents were overdue expiry date (46\%) and excessive shopping (37\%). Among the reasons for throwing away food, respondents also indicated the lack of idea for the use of ingredients in the household $(10 \%)$, the purchase of qualitatively bad products $(4 \%)$ and the lack of a shopping list (3\%).

In the surveyed households, bread was most often thrown away. Such a response was indicated by almost every second respondent. The results of the presented research are consistent with the results of other scientists, who also show that the product most often thrown away is bread (Deloitte, 2017; Banki Żywności, 2018). The group of products most often wasted also includes cold cuts (37\%), vegetables (37\%) and fruit (32\%). Every fourth person indicated yoghurt (26\%) and every eighth person indicated milk (14\%). The basket also included ready meals $(11 \%)$, cheese $(9 \%)$ and meat (8\%). Eggs (3\%) and fish (2\%) were the least frequently indicated.

The overall financial literacy indicator and its three modules have been calculated for the entire population, as well as for the group of people wasting food and respondents whose households did not experience this phenomenon.
According to the conducted research, the respondents were characterized by an average level of financial literacy. The average score obtained is 12.6 points $(\mathrm{SD}=2.9)$. The lowest score obtained is 3 points, the maximum is 20 points. The average result obtained for the studied group was consistent with the average result obtained for the adult population of Poland (OECD INFE, 2016). Compared to other EU countries, Poland has one of the lowest levels of financial literacy in the European Union. Statistical analysis shows that people who waste food have a slightly lower level of financial literacy compared to respondents who declared that they do not throw away food. The average score for the first group was 12.5 points, while for those who indicated that food is not wasted in their farms it was 12.7 points. The conducted analysis did not show a statistically significant difference between the average result of financial literacy of people who do not waste food and respondents who throw away food (Table 2).

One of the elements creating financial literacy is basic financial knowledge. The level of financial knowledge of the respondents was assessed by means of 7 questions. These questions concerned the calculation of the interest rate, the mechanism of compound interest rate, inflation, diversification of the financial portfolio or the relationship between the amount of risk and the rate of return. The respondent received 1 credit for each correct answer. Respondents could obtain 0 points in this part of the test at least and 7 points at most.

On average, respondents answered 5 questions correctly $(17 \%$ of respondents). Almost $2 \%$ of the surveyed population did not answer any question correctly, and almost $15 \%$ of consumers achieved the maximum score (7 points). Respondents best dealt with the question about the relationship between risk and rate of return on financial instruments. In this case, the highest number of correct answers was given (91\%). The question that caused the most problems

\begin{tabular}{|l|c|c|c|c|}
\hline \multirow{2}{*}{ Specification } & \multicolumn{2}{|c|}{ Wasting food } & \multirow{2}{*}{ the F test } & $\mathrm{p}$ \\
\cline { 2 - 3 } & $\begin{array}{c}\text { Yes } \\
\text { M (SD) }\end{array}$ & $\begin{array}{c}\text { No } \\
\text { M (SD) }\end{array}$ & $\mathrm{F}=0.413$ & $\mathrm{p}=0.521$ \\
\hline Finacial literacy & $12.5(2.8)$ & $12.7(3.1)$ & $\mathrm{F}=1.763$ & $\mathrm{p}=0.185$ \\
\hline Financial knowledge & $4.0(1.9)$ & $4.3(2.0)$ & $\mathrm{F}=0.525$ & $\mathrm{p}=0.469$ \\
\hline Financial behaviours & $5.9(1.8)$ & $6.0(1.8)$ & $\mathrm{F}=5.448$ & $\mathrm{p}=0.020^{*}$ \\
\hline Financial attitudes & $2.4(3.1)$ & $2.6(2.8)$ & & \\
\hline
\end{tabular}

Note: * statistical significance at $\mathrm{p}<0.05$

Source: own calculations

Table 2: Average results obtained by respondents in the financial literacy modules. 
to the respondents concerned the compound interest rate. Only 4 out of 10 persons knew the correct answer to this question.

The average score achieved by the tested group is 4.1 points $(\mathrm{SD}=2.0)$. This result is consistent with the results achieved for Poland in OECD INFE surveys (2016). As shown in Table 2, there was no statistically significant difference in the average result for the module "Financial knowledge" between people wasting food and respondents who declared that in their households food is not thrown away. The average score for the first group is 4.0 points, while for the second group it is 4.3 points.

Another module that creates financial literacy are financial behaviours. Financial behaviours means the deliberate or unintentional management of personal finances during a defined period of time. Respondents' financial behaviour was assessed by 9 questions. These questions concerned the degree of independence in daily financial decision-making, the ability to draw up a household budget, active saving, the willingness to pay bills on time, prudent shopping and setting financial targets. For each rational behaviour the respondents could get 1 point. The minimum result from this part is 0 points, the maximum - 9 .

The average score for the tested group is 5.9 points $(\mathrm{SD}=1.8)$. This result is higher than presented in the literature. In the already quoted OECD INFE studies, the average score for Poland in this module is 4.4 points (OECD INFE, 2016). The above discrepancy may result from the fact that OECD studies were conducted in 2015, and as noted by E. Kieżel and A. Burgiel (2017) and M. Musiał (2018), the level of financial literacy of Poles is systematically increasing.

In this module, respondents most often received 6 points $(21 \%$ of persons). Less than $1 \%$ of the surveyed population did not score any points in this part. Every twentieth respondent received a maximum number of points. Among the financial behaviors mentioned in the questionnaire, the highest number of positive declarations (81\%) received the statement "I pay my bills on time". On the other hand, the least positive answers were found in the case of the question on regular household income and expenditure records. Only $1 / 3$ of the respondents prepared a household budget. Most of the respondents have never heard of such a practice. Awareness of the budgets of a consumer should be the basis for rational spending planning for each person.
Financial attitudes are the last element of financial literacy. The questionnaire included three questions to assess respondents' attitudes towards money and financial planning. The claims made in the questionnaire were "I tend to live for today and let tomorrow take care of itself", "I find it more satisfying to spend money than to save it for the long term", "Money is there to be spent" (OECD, 2016, p. 50). In order to assess attitudes, the five-point Likert scale was used, where 1 meant that the respondent fully agrees with the statement, 5 - completely disagrees. The content of the questions concerned attitudes in the short term, so if the respondent did not agree with the statement (answers 4 and 5) it meant that he or she had such an attitude in the long term (attitudes desirable from the point of view of rationality of consumer behaviours). The points marked by the respondents were summed up and the value obtained was divided by 3 . The minimum number of points in this module was 1 and the maximum number was 5 .

The average result obtained by the respondents is 2.6 points $(\mathrm{SD}=2.9)$. Most respondents from this part of the test received 2 points $(36 \%)$. The minimum score (1 point) was obtained by $13 \%$ of respondents, the maximum score (5 points) by $3 \%$ of respondents.

The statistical analysis demonstrated significant differences in the average result of this financial literacy module between people who do not waste food and consumers who throw food away (Table 2). Consumers wasting food were more likely to adopt a more consumption-oriented approach to spending money than those not wasting food. They were more satisfied with spending money than with saving it for the future. More than $40 \%$ of the people in this group thought that money was meant to be spent. For comparison, in the group of people declaring that they do not throw away food, this attitude was shown by less than $30 \%$ of the respondents.

Due to the fact that among the elements creating financial literacy only consumer financial attitudes influence their tendency to waste food, in order to determine the likelihood of the impact of financial literacy on food waste in households, only this financial literacy module was taken into account in the built model.

To determine the probability of the financial attitudes impact on the tendency to waste food in comparison with other determinants, seven demographic and economic factors were used 
to build the model (independent variables). The characteristics of these variables are given in Table 3.

The results of the logistic regression model estimation for seven independent variables are presented in Table 4.

For the model obtained, the chi-square value (44.206) is statistically highly significant $(\mathrm{p}=0.000)$. As can be seen from the results sheet (Table 4), the variables: financial attitudes $\left(X_{1}\right)$, education $\left(\mathrm{X}_{4}\right)$, place of residence $\left(\mathrm{X}_{5}\right)$ and average net income per capita in the respondent's household $\left(\mathrm{X}_{7}\right)$ significantly affect consumers' willingness to waste food. Other factors such as gender $\left(\mathrm{X}_{2}\right)$, age $\left(\mathrm{X}_{3}\right)$ and the number of persons in the household $\left(\mathrm{X}_{6}\right)$ turned out to be insignificant (level $\mathrm{p}<0.05$ ). Therefore, a simpler model without these variables was considered at a later stage of the study. Only statistically significant determinants were taken into account in the analysis. The obtained values are presented in Table 5 .

\begin{tabular}{|c|l|l|}
\hline $\begin{array}{c}\text { Symbol } \\
\text { of the variable }\end{array}$ & \multicolumn{1}{|c|}{ Name of the variable } & \multicolumn{1}{c|}{ Unit of measure } \\
\hline$Y$ & Wasting food & Dependent variable (1 - Yes, 0 - No) \\
\hline$X_{1}$ & Financial attitudes (FA) & Independent quantitative variable (scale 1-5 points) \\
\hline$X_{2}$ & Gender & Independent qualitative variable (1- Female, 0 - Male) \\
\hline$X_{3}$ & Age & Independent qualitative variable (scale 1-4) \\
\hline$X_{4}$ & Education & Independent qualitative variable (scale 1-3) \\
\hline$X_{5}$ & Place of resindence & $\begin{array}{l}\text { Independent qualitative variable (1 - village, 2 - a city } \\
\text { of up 100,000 inhabitants, 3 - city over 100,000 inhabitants) }\end{array}$ \\
\hline$X_{6}$ & Number of persons in the household & Independent quantitative variable \\
\hline$X_{7}$ & Average net income per capita in the households & Independent qualitative variable (scale 1-6) \\
\hline
\end{tabular}

Source: own calculations

Table 3: Characteristics of variables used for logistic regression analysis (seven independent variables).

\begin{tabular}{|c|l|c|c|c|}
\hline $\begin{array}{c}\text { Symbol } \\
\text { of the variable }\end{array}$ & \multicolumn{1}{|c|}{ Name of the variable } & Parameter rating & Significance & Odds ratio W \\
\hline$X_{1}$ & Financial attitudes (FA) & -0.276 & $0.010^{*}$ & 0.758 \\
\hline$X_{2}$ & Gender & 0.260 & 0.242 & 1.296 \\
\hline$X_{3}$ & Age & 0.040 & 0.359 & 1.042 \\
\hline$X_{4}$ & Education & -0.505 & $0.000^{*}$ & 0.604 \\
\hline$X_{5}$ & Place of residence & 0.272 & $0.033^{*}$ & 1.313 \\
\hline$X_{6}$ & Number of persons in the household & -0.080 & 0.386 & 0.923 \\
\hline$X_{7}$ & Average net income per capita in the households & -0.294 & $0.000^{*}$ & 0.745 \\
\hline- & Constant & 0.892 & 0.242 & 2.439 \\
\hline
\end{tabular}

Note: * statistical significance at $\mathrm{p}<0.05$

Source: own calculations

Table 4: Evaluation of the logistic regression model parameters describing selected factors influencing the probability of food waste in Polish households (7 variables).

\begin{tabular}{|c|l|c|c|c|}
\hline $\begin{array}{c}\text { Symbol } \\
\text { of the variable }\end{array}$ & \multicolumn{1}{|c|}{ Name of the variable } & Parameter rating & Significance & Odds ratio W \\
\hline$X_{1}$ & Financial attitudes (FA) & -0.260 & $0.015^{*}$ & 0.771 \\
\hline$X_{4}$ & Education & 0.515 & $0.000^{*}$ & 0.598 \\
\hline$X_{5}$ & Place of residence (Place) & 0.298 & $0.015^{*}$ & 1.347 \\
\hline$X_{7}$ & $\begin{array}{l}\text { Average net income per capita in the households } \\
\text { Income) }\end{array}$ & 0.277 & $0.001^{*}$ & 0.758 \\
\hline- & Constant & 1.004 & $0.042^{*}$ & 2.728 \\
\hline
\end{tabular}

Note: * statistical significance at $\mathrm{p}<0.05$

Source: own calculations

Table 5: Evaluation of the logistic regression model parameters describing selected factors influencing the probability of food waste in Polish households (four variables) 
Taking into account the estimated model factors, the logistic regression model for four independent variables takes the following form:

$P(Y=1)=\frac{e^{1.004-0.260 F A+0.515 E D U C A T I O N+0.298 P L A C E+0.277 I N C O M E}}{1+e^{1.004-0.260 F A+0.515 E D U C A T I O N+0.298 P L A C E+0.277 I N C O M E}}$

Parameter $a_{0}=1.004$ is the logarithm of the odds indicator for the base level. Analysis of model parameters from b1 to b4 includes analysis of coefficient signs. The sign of the coefficient "-" means that the predicted probability of food waste decreases for each unit increase of the independent variable (in the presented model these are financial attitudes, $b_{1}=-0.260$ ). The sign "+" of the coefficient means the increase in the likelihood of food waste along with the increase of each unit increase of the independent variable (in the discussed model variables: education; $b_{2}=0.515$, place of residence; $b_{3}=0.298$ and income, $b_{4}=0.277$ ).

Among the factors taken into account in the model, the probability of wasting food in households is most strongly influenced by the respondent's education. The higher the respondent's education, the higher the share of people who waste food. According to the model, the logarithm of the odds indicator waste food increases by 0.515 for each increase of this variable by one unit (by one level of education). The odds ratio $\mathrm{W}=0.598$, which means that an increase in education by one level increases the probability of wasting food by 0.598 times. The results obtained are consistent with the results presented in the literature, which show that the best educated people are the "highest" food wasters (Stefan et al., 2013). In their research (2007) Cox and Downing obtained opposite results. According to these authors, families with low incomes tend to waste a bigger amount of food.

As may be seen in subject literature, there is an unusually strong correlation among the education level and income, and the influence of these factors on food waste in households (Porfino et al., 2017). Therefore, the analysis was conducted to investigate the inclination for food wasting by the respondents on the same level of income but with different level of education. As results from the investigations, in the first four groups, identified on the basis of income, the higher the level of education, the smaller the share of food wasting persons. On the other hand, in the other two respondent groups (households where the average net income per capita was the highest), the problem of food waste was the most rarely noticed in the households of persons with secondary education. Food was most frequently thrown away by households of respondents possessing vocational and university education.

The tendency to waste food also depends on the place of residence. The larger the place of residence, the likelihood of food waste increases (the logarithm of the odds indicator - parameter rating $=0.298$ ). According to the odds ratio indicator $(\mathrm{W}=1.347)$, inhabitants of large towns throw food 1.3 times more often than those in small towns/ villages. This dependence should be connected with several facts. Firstly, rural households, and in particular farmers' households, have some of the lowest incomes in Poland. Secondly, rural dwellers use food waste to feed animals. According to law it is considered as a food waste (for example in Slovakia). Thirdly, food and especially bread in the Polish tradition and rural customs enjoys great respect, so the phenomenon of wasting food is less frequent. G. Porpino, J. Parente and B. Wansink (2017), who studied Brazilian households, also noticed a positive relationship between tradition and culture and limiting food waste.

Another factor that increases the likelihood of food wastage is income. The higher the respondent's income, the higher the share of consumers who waste food. According to the model, the logarithm of the odds indicator waste food increases by 0.277 (parameter rating) for each increase of this variable by one unit (by PLN 500/EUR $120)$. The odds ratio $\mathrm{W}=0.758$, which means that an increase in average net income per capita in the households by one level increases the probability of wasting food by nearly 0.8 times. D. Baker, J. Fear and R. Denniss (2009) also observed the impact of consumer income on the tendency to waste food. In their research they estimated the value of food thrown away in Australian households. For households with an income not exceeding $\$ 40,000$ per year, the value of food thrown away is $\$ 518$ a year. This compares with food waste of $\$ 635$ a year for Australian households with an income between $\$ 40,000$ and $\$ 80,000$. The households earning more than $\$ 80,000$ a year are wasting $\$ 803$ in food annually.

Studies conducted by M. Setti, L. Falasconi and M. Vittuari (2016) on the group of 1,403 Italian food consumers show that there are complex relationships between per capita income and household food waste behavior. Lower income class consumers show a greater attitude to waste certain food typologies. Mid-to-low income consumers purchase higher amounts of lower quality products, therefore waste more food. 
Slightly weaker than income, the likelihood of wasting food is affected by consumers' attitudes towards money. A negative estimation of the parameter for the variable FA (financial attitudes) indicates that an increase in this value results in a decrease in the probability of wasting food in households (parameter rating $=-0.260$ ). At the adopted indications $(\mathrm{Y}=1$ means food wastage, $\mathrm{Y}=0$ the phenomenon does not occur), the calculated odds ratio $\mathrm{W}=0.771$ informs that the probability of food wastage decreases by 0.8 times in the group of people characterized by a higher level of FA.

\section{Conclusion}

In the conducted research the relationship between the level of consumer financial literacy and their tendency to waste food was analyzed. According to the F test, the general level of financial literacy does not significantly affect the fact that food is wasted in consumers' households $(\mathrm{F}=0.413$, $\mathrm{p}>0.05)$. Both persons with a low and medium level of financial literacy and consumers with a high level of financial competence wasted food equally.

The overall financial literacy indicator consists of three modules: basic financial knowledge, financial behaviours and financial attitudes. The conducted analysis demonstrates that among the elements creating financial literacy, only financial attitudes determine consumers' inclination to waste food. The higher the score obtained from this module, the share of people not wasting food is increasing. The influence of financial attitudes on consumers' tendency to waste food or limit this phenomenon results from different consumer attitudes towards money, spending and saving. These attitudes may be modified as a result of conscious educational activities in the field of personal finances concerning effective and rational management of household budget, including spending on food, which will reduce the problem of food waste

The methodology used in the research allowed to identify a set of the most important demographic and economic determinants influencing the fact of wasting food by consumers in their households. It also indicates which of these factors are the most important and which are of marginal importance. Factors that significantly influence consumer behavior related to food wastage were the place of residence, net income per capita in the consumer's household, education level and financial attitudes. The level of education has the strongest impact on the likelihood of wasting food. The higher the education, the higher the tendency to waste food. From the group of factors that significantly determine the occurrence of food wastage, financial attitudes have the weakest impact. The factors that do not determine the tendency to waste food were: gender, age and the number of people in the household.

Because of selected data analysis method, the investigations took into account only the fact whether food waste occurred in a given household or not. In subsequent analyses it would be important to determine also the dependence between the amount of wastes and determinants of the food waste level, but also to study the relationship between the percentage of wasted food in relation to the households' incomes. The kind of wastes should be also considered.

In the studies discussed above, consumers' financial attitudes were assessed by means of three questions (core questionnaire OECD INFE). Due to the fact that financial attitudes are the only module of financial literacy that determines consumers' inclination to waste food, an interesting direction of research would be a detailed analysis of consumer financial attitudes towards their inclination to waste food. The planned research should use one of the internationally recognized scales that measure consumers' attitudes towards money, such as the Money Attitude Scale (MAS) concept by $\mathrm{K}$. Yamauchi and D. Templer, Money Beliefs and Behaviour Scale (MBBS) by A. Furnhama or The Love of Money Scale by T. Li-Ping Tang.

Corresponding authors

Ing. Monika Szafrańska, PhD.

University of Agriculture in Cracow, Al. Mickiewicza 21, 31-120 Cracow, Poland

Phone: +481266243 72,E-mail:m.szafranska@ur.krakow.pl

ORCID: 0000-0002-4948-7636 


\section{References}

[1] Aschemann-Witzel, J., Jensen, J., Jensen M. and Kulikovskaja V. (2017) "Consumer behaviour towards price-reduced suboptimal foods in the supermarket and the relation of food waste in households", Appetite, Vol. 116, pp. 246-258. ISSN 0195-6663. DOI 10.1016/j.appet.2017.05.013.

[2] Baker, D., Fear, J. and Denniss, R. (2009) "What a waste - an analysis of household expenditure on food”, Policy Brief, Vol. 6, pp. 1-24. ISSN 1836-9014.

[3] Banki Żywności (2018) "Report of the Federation of Polish Food Banks 2018 - I'm not wasting food" [Online]. Available: https://bankizywnosci.pl/wp-content/uploads/2018/10/Przewodnik-doRaportu_FPBZ_-Nie-marnuj-jedzenia-2018.pdf [Accessed: 9. Sep. 2019] (In Polish).

[4] Cox, J. and Downing, P. (2007) "Food Behaviour Consumer Research: Quantitive Phase", Retail Programme - Food Waste: Final Report, Wrap, Banbury, UK, [Online]. Available: http://www.wrap. org.uk/sites/files/wrap/Food\%20behaviour\%20consumer\%20research\%20quantitative\%20jun $\% 20$ 2007.pdf [Accessed: 9. Sep. 2019].

[5] Deloitte (2018) "Poland in the lead of the EU countries wasting the most food". [Online]. Available: https://www2.deloitte.com/pl/pl/pages/press-releases/articles/Polska-w-czolowce-panstw-UEmarnujacych-najwiecej-zywnosci.html [Accessed: 9. Sep. 2019] (In Polish).

[6] Evans, D. (2011) "Blaming the consumer - once again: the social and material contexts of everyday waste practices in some English households", Critical Public Health, Vol. 21, pp. 429-440. ISSN 0958-1596. DOI 10.1080/09581596.2011.608797.

[7] FAO (2011)"Global food loses and food waste. Extent, causes and prevention", FAO, Rome. ISBN 978-92-5-107205-9.

[8] FAO (2013) "Food wastage footprint Impacts on natural resources". [Online]. Available: http://www.fao.org/3/i3347e/i3347e.pdf [Accessed: 3. Nov. 2019].

[9] FAO (2014) "The Food Losses and Food Waste in Europe and in Central Asia", FAO Regional Conference for Europe and Central Asia, 2014, Bucurest, Romania. [Online]. Available: http://www. fao.org/about/meetings/erc29/en/ http://www.wrap.org.uk/sites/files/wrap/Food\%20behaviour\%20 consumer\%20research\%20q [Accessed: 9. Sep. 2019]

[10] Graham-Rowe, E., Jessop, D. and Sparks P. (2014) "Identifying motivations and barriers to minimizing households food waste", Resources, Conservation and Recycling, Vol. 84, pp. 15-23. ISSN 0921-3449. DOI 10.1016/j.resconrec.2013.12.005.

[11] GUS (2017) "Statistical Yearbook of the Republic of Poland", Zakład Wydawnictw Statystycznych, Warszawa, ISSN 1506-0632.

[12] Kieżel E. and Burgiel A. (2017) "Economic knowledge of consumers and the rationality of their behaviours", Wydawnictwo C. H. Beck, Warszawa. ISBN 978-83-812-8042-6. (In Polish).

[13] Jörissen, J., Priefer, J.and Bräutigam, K. (2015) "Food waste generation at household level: results of a survey among employees of two European research centers in Italy and Germany", Sustainability, Vol. 7, No. 3, pp. 1-21. ISSN 2071-1050.

[14] Koivupuro, H.-K., Hartikainen, H., Silvennoinen, K., Katajajuuri, J.-M., Heikintalo, N., Reinikainen, A. and Jalkanen L. (2012) "Influence of socio-demographical, behavioural and attitudinal factors on the amount of avoidable food waste generated in Finnish households", International Journal of Consumer Studies, Vol. 36, pp. 183-191. ISSN 1470-6431. DOI 10.1111/j.1470-6431.2011.01080.x.

[15] Macková, M., Hazuchová, N. and Stávková, J. (2019) “Czech consumers' attitudes to food waste", Agricultural Economics - Czech, Vol. 65, pp. 314-321. ISSN 1805-9295. DOI 10.17221/364/2018-AGRICECON.

[16] McCarthy, B. and Liu, H. (2017) 'Food waste and the 'green' consumer", Australasian Marketing Journal, Vol. 25, pp. 126-132. ISSN 1441-3582. DOI 10.1016/j.ausmj.2017.04.007. 
[17] Milne, R. (2013) "Food Waste and Sustainable Food Waste Management in the Baltic Sea Region", Springer, Hamburg, Germany. ISBN 978-3-319-10906-0.

[18] Musiał, M. (2018) "Effectiveness of personal finance management in Poland", Rozprawy i Studia, Wydawnictwo Naukowe Uniwersytetu Szczecińskiego, Szczecin, ISSN 0860-2751. (In Polish).

[19] OECD INFE (2011) "Measuring Financial Literacy Questionnaire and Guidance Notes for Conducting an Internationally Comparable Survey of Financial Literacy" [Online]. Available: www.oecd.org/finance/financial-education [Accessed: 9. Sep. 2019].

[20] OECD INFE (2016) "International Survey of Adult Financial Literacy Competencies", [Online]. Available: www.oecd.org/finance/financial-education [Accessed: 9. Sep. 2019]

[21] Parfitt, J., Barthel, M. and Macnaughton S. (2010) "Food waste within food supply chains: quantification and potential for change to 2050", Philosophical Transactions of the Royal Society Biological Sciences, Vol. 365, pp. 3065-3081. ISSN 1563-0447. DOI 10.1098/rstb.2010.0126.

[22] PCPM (2019) "Children on the edge of death". [Online]. Available: https://pcpm.org.pl/dzieci-nakrawedzi-smierci-szesc-agend-onz-apeluje-o-pomoc-w-walce-z-masowym-niedozywieniem.html [Accessed: 9. Sep. 2019].

[23] Plumb, A. and Downing, P. (2013) "Consumer Attitudes to Food Waste and Food Packaging”, Waste \& Resources Action Programme, Barbury, UK. ISBN 978-1-84405-465-7.

[24] Porpino, G., Parente, J. and Wansink, B. (2017) "Food Waste Paradox: Antecedents of Food Disposal in Low-Income Households", International Journal of Consumer Studies, Vol. 39, No. 6, pp. 619-629. ISSN 1470-6423. DOI 10.1111/ijcs.12207

[25] Quested, T., Parry, A., Easteal, S. and Swannell, R. (2011) "Food and drink waste from household in the UK", Nutrition Bulletin, Vol. 36, No. 4, pp. 460-467. ISSN 1467-3010. DOI 10.1111/j.1467-3010.2011.01924.x.

[26] PEI (2019) "Poland occupies fifth place in EU for food waste" [Online]. Available: https://www. thefirstnews.com/article/poland-occupies-fifth-place-in-eu-for-food-waste-7074 [Accessed: 3. Nov. 2019]

[27] Ratinger, T., Tomka, A. and Boskova I. (2016) "Sustainable consumption of bakery products; a challenge for Czech consumers and producers", Agricultural Economics - Czech, Vol. 62, pp. 447-458. ISSN 1805-9295. DOI 10.17221/244/2015-AGRICECON.

[28] Richter, B. and Bokelmann, W. (2018) "The signigicance of avoiding household food waste - A means-end-chain-approach", Waste Management, Vol. 74, pp. 34-42. ISSN 0956-053X. DOI 10.1016/j.wasman.2017.12.012.

[29] Setti, M., Falasconi, L. and Vittuari, M. (2016) "Italian consumers' income and food behavior", British Food Journal, Vol. 118, No. 7, pp. 1731-1746. ISSN 0007-070X. DOI 10.1108/BFJ-11-2015-0427.

[30] Stanisz, A. (2011) "Intelligibe statistic course", StatSoft Polska Sp z o.o., Kraków. ISBN 83-88724-18-5. (In Polish).

[31] Stefan, V., van Herpen, E., Tudoran, A. A. and Lähteenmäki L. (2013) "Avoiding food waste by Romanian consumers: The importance of planning and shopping routines", Food Quality and Preference, Vol. 28, pp. 375-381. ISSN 0950-3293. DOI 10.1016/j.foodqual.2012.11.001.

[32] Szreder, M. (2004) "Methods and techniques of opinion polls", Polskie Wydawnictwo Ekonomiczne, Warszawa. ISBN 83-208-1515-0. (In Polish). 